\title{
Evidence for Two Sets of Cytoplasmic Microtubules in Interphase and Preprophase Cells of Onion Root. An Immunofluorescence Study
}

\author{
Jacek Z. Kubiak ${ }^{1}$ and Jadwiga A. Tarkowska \\ Department of Anatomy and Cytology of Plants, University of Warsaw, 00-927 \\ Warszawa, Krakowskie Przedmieście 26/28, Poland
}

Accepted August 7, 1986

The cytoplasmic microtubules (MTs) of plant cells play an essential role in cell-wall deposition (Heath 1974) and cell shaping (Dustin 1978, Lloyd et al. 1980). These functions are fulfilled by cortical MTs located close to the plasmalemma in cells possessing a wall. The presence of cytoplasmic MTs in interphase animal cells was shown with immunocytochemical methods (Brinkley et al, 1975, Weber et al. 1975). It is more difficult to exhibit them with these methods in plant cells because of the cell wall and the thickness of the cells. Both these shortcomings are omitted in the case of flattened and wall-free Haemanthus endosperm cells. De Mey et al. (1982), Molè-Bajer and Bajer (1983) and Schmit et al. (1983) showed the arrangements of MTs with help of immunocytochemistry in this material. These cells do not possess any cortical MTs, but a complex of MTs radiating from the nuclear envelope (NE). Wick et al. (1981) and Wick and Duniec (1983) visualized interphase cortical MTs in wall-digested and shape-stabilized onion root cells. They showed that the cortical MTs are arranged in ribbons perpendicular to the long cell axis.

In this paper we distinguish cortical and endoplasmic MT arrays in the interphase and early preprophase cells of onion roots revealed with indirect immunofluorescence and show that the first may be composed in various patterns correlating with the shape of cells. Our main purpose was to investigate how both the sets of microtubules behave during interphase-mitosis transition and if they differ functionally. We state on the basis of morphological differences, various behaviour during preprophase and different sensitivity to colchicine that both the sets of MTs create morphologically as well as functionally distinct entities during interphase and preprophase. In addition we show different sensitivity of the cortical interphase vs. mitotic microtubules to the action of clochicine.

\section{Material and methods}

The observations were carried out on onion (Allium cepa L.) root tips cells stained with indirect immunofluorescence for MTs. The procedure was described in details by Kubiak et al. (1985). The root tips were fixed in 0.5 or $1 \%$ glutaraldehyde in microtubule stabilizing buffer (PHEM). Permeabilization was done with $50 \%$ ethanol supplemented with $0.5-5 \mathrm{mg} / \mathrm{ml}$ $\mathrm{NaBH}_{4}$ or in $0.5 \%$ Triton X-100 with further incubation in $0.5-5 \mathrm{mg} / \mathrm{ml} \mathrm{NaBH}_{4}$.

An affinity purified rabbit antitubulin antibody against dog brain tubulin was used as the first antibody and GAR IgG-FITC as the second one.

Some roots were incubated in $5 \times 10^{-2} \mathrm{M}$ colchicine dissolved in tap water. The roots were fixed according to the above procedure after $45 \mathrm{~min}$., 1.5 and $3 \mathrm{hrs}$ of incubation. Acetoorcein staining of squash preparations was used to determine whether C-mitoses are present.

${ }^{1}$ Present address: Department of Embryology, Institute of Zoology, University of Warsaw, 00-927 Warszawa, Krakowskie Przedmieście 26/28, Poland. 

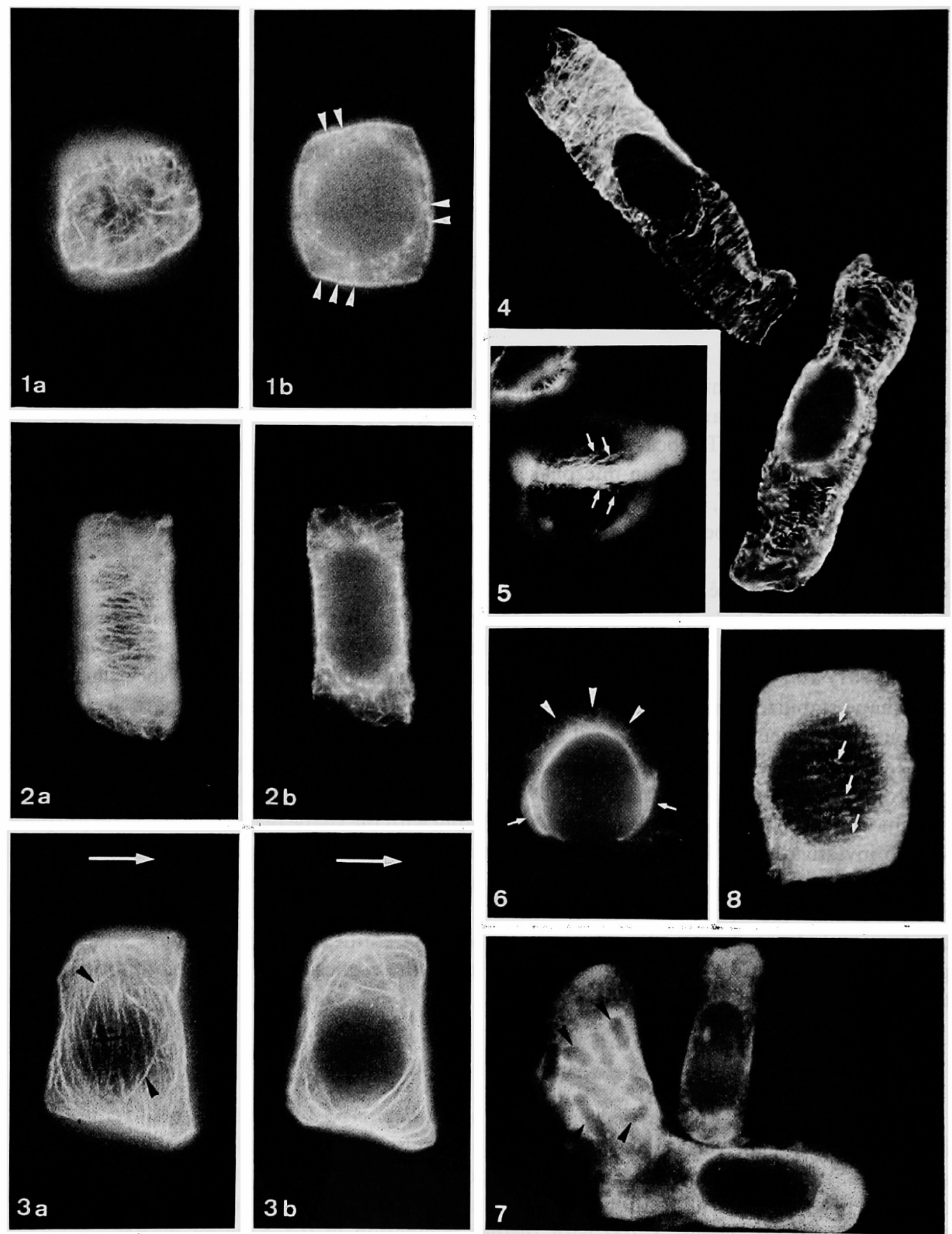

Figs. 1-8. 1a, b: The cubic interphase cell at two levels of focus. 1a, the upper surface of the cell revealing the random MTs arrangement. 1b, the middle plane of this same cell. The sheet of cortical MTs beneath the plasmalemma (arrowheads) and the array of random MTs in the endoplasm is visible. Note the nucleus free of staining. $\times 1500.2 \mathrm{a}, \mathrm{b}$ : Flongated cell at two levels of focus. 2a, the upper surface of the cell. MTs form mainly transverse ribbons or rings in the cortical region of the cell. 2b, the middle plane of this same cell. Note the network of endoplasmic MTs between the stain-free nucleus and the plasmalemma. $\times 1500$. 3a, b: Slightly elongated cell at two levels of focus. 3a, the upper surface of the cell. Most of MTs are running according to the long cell axis. Some of them form arcs (arrowheads). 3b, the endoplasmic MTs form a netwrok in the cytoplasm 
The preparations were observed and photographed under Nikon Labophot and Polyvar, Reichert Jung photomicroscopes on Kodak TX-400 films.

\section{Results}

The meristematic root cells in interphase possess characteristic patterns of cortical microtubules. In the case of cubic or isodiametric cells we observed random MT arrangements. The cortical MTs form multidirectional networks without any particular pettern (Fig. 1a). In elongated cells the ribbons or rings of cortical MTs run round the narrow periphery of the cells (Fig. 2a). However in such cells we observed also some MTs running obliquely or along the long cell axis, but always in great minority (Figs. 2a, 4). On the other hand in some cells cortical MTs course mainly round the long axis of the cell. The latter pattern was characteristic for only slightly elongeted cells (Fig. 3a).

Focussing through each cell we observed the endoplasmic MTs. They form three-dimensional networks in the cytoplasm of the cells (Figs. $1 \mathrm{~b}, 2 \mathrm{~b}, 3 \mathrm{~b}$ ). The nuclei are free of these MTs (Figs. 1b, 2b, 3b, 4).

Both types of interphase MT arrays changed drastically during preprophase. Two structures were found during this stage: the preprophase band of MTs (PPB) in the cortical region of the cell and the nuclear envelope-associated frame (NEAF) around the nucleus. The PPB in early stages of development contains numerous MTs running obliquely or archwisely to the main direction of PPB microtubules (Fig. 5). The MTs of the NEAF exhibit feathery arrangement (Fig. 6). Until late preprophase one can distinguish cortical MTs arranged in a PPB structure and endoplasmic MTs as a nuclear envelope-associated frame.

Colchicine in relatively high concentrations $5 \times 10^{-2} \mathrm{M}$ caused $\mathrm{C}$-mitoses just after 45 minutes of incubation as orcein stained preparations showed (data not shown). In the immunofluorescence counterparts no traces of mitotic MTs or phragmoplast were present (Fig. 7), but neighbour interphase cells revealed only partially disassembled cortrical MTs (data not shown) and no distinctive endoplasmic ones (Fig. 7). Up to the third hour of incubation we could still distinguish, although rather diffuse, traces of cortical MTs (Fig. 8).

\section{Discussion}

It is known from ultrastructural studies (Ledbetter and Porter 1970, Hardham and Gunning 1977, 1978, Gunning and Hardham 1979) and immunofluorescences (Wick and Duniec 1983, Clayton and Lloyd 1984) that the cortical MTs in interphase root cells form rings or ribbons transverse to the long axis of a cell. Such a transverse disposition was also described in carrot protopasts cultured in vitro (Lloyd et al. 1979), in onion leaf sheath cells before the formation of bulbs (Mita and Shibaoka 1983) and in elongating cells of Vicia hajastana treated with gibberelin (Simmonds et al. 1982, 1983a, b).

of the same cell. The arrows mark suspected direction of elongation. $\times 1500$. 4 , two highly elongated cells. MTs form transverse ribbons at the cortex of these cells. The nuclei are free of staining. $\times 1100$. 5, the preprophase cell. MTs on both sides of the PPB are oblique to the band and form arcs (arrows). $\times 1500.6$, the preprophase cell. NEAF MTs form feathery structures around the nucleus (arrowheads) and PPB MTs are restricted only to the cortical region (arrows). $\times 1500,7,1.5 \mathrm{~h}$. action of $5 \times 10^{-2} \mathrm{M}$ colchicine on onion root. Two interphase cells at the middle focal plane (right) possess diffused staining in their cytoplasm and no traces of endoplasmic MTs. Nuclei are free of staining. The C-metaphase cell (left) reveals dark chromosomes (arrowheads) in the mass of bright ly stained cytoplasm. $\times 1100.8$, interphase cell. $3 \mathrm{hrs}$ action of $5 \times 10^{-2} \mathrm{M}$ colchicine. One may distinguish traces of remnants of transverse cortical MTs (arrows). $\times 1500$. 
The majority of onion root tip cells have also the transverse arrangement of MTs, but such an arrangement is not the only pattern of cortical MTs. Some isodiametric or cubic cells possess an irregular network of cortical MTs. A similar arrangement was described by Lloyd and co-workers (1979) in carrot cells with previously digested cell walls, the protoplast concomitantly changed their shape from elongated to an oval one. Another example of MT pattern changes from transverse to irregular was noticed by Mita and Shibaoka (1983) during the swelling of leaf sheath cells at the stage of bulb formation. Simmonds et al. (1983a, b) described such a disorderd pattern in cultured Vicia hajastana cells in early interphase i.e. when the cortical MT array was formed just after mitosis and in freshly prepared protoplasts of the same cultured cells. In the light of this data we suggest that the variable patterns of cortical MTs observed in onion root cells are directly connected with the changes of their shape. From the observations on squash preparations it is difficult to decide from which part of a root the cells originate. The shape of the cubic cells, however, suggests that they are meristematic cells before their elongation or that they just completed mitosis and are at the stage of reorganization of the MT pattern. Trying to explain the origin of the "reversed" pattern of cortical MTs i.e. the ribbons running round the long axis, in slightly elongated cells, we suggest that in fact they represent cells which passed longitudinal division, but their elongation will proceed along their short and not long axis. In consequence after elongation they reach typical for such cells pattern of transverse MTs.

The endoplasmic MTs we revealed focussing through the cells do not form any charactersitic pattern. They fill up the cytoplasm between the vacuoles and the nucleus. De Mey et al. (1982), Molè-Bajer and Bajer (1983) and Schmit et al. (1983) showed in the endosperm cells of Haemanthus katherinae and Clivia nobilis also Dickinson and Sheldon (1984) in the young microspores of Lilium that the interphase MTs radiate from the nuclear envelope or are anchored to it. Both these types of cells differ significantly from the root cells by the lack of a cellulose wall. This function played by endoplasmic MTs in the first (Schmit et al. 1983) seems to be fulfilled by cortical MTs together with the cell-wall in the second (Lloyd et al. 1980). The network of endoplasmic MTs in interphase onion root cells may play some role in intracelluar transport or positioning of the nucleus and they may be used as material for the NEAF of the preprophase.

Our experiments with colchicine suggest that the both populations of MTs (cortical and endoplasmic) differ in their sensitivity to this drug. The cortical MTs are more resistant to the colchicine action than the endoplasmic or mitotic ones. Such a response to this drug may be implication of their differnt properties. For example, cortical MTs may show lower turnover than the endoplasmic and mitotic MTs. Alternatively, the cortical MTs may be built up of slightly different tubulins or may have other proteins associated with them.

The existence of two distinct sets of MTs in the interphase onion root tip cells was also observed during preprophase. At this stage cortical MTs form a PPB and the endoplasmic MTs seem to accumulate in the neighbourhood of the nuclear envelope in the form of disassembled tubulin or short microtubules forming the NEAF. In concludion: both sets of MTs behave during interphase and preprophase as distinct morphologically and functionally entities.

\section{Summary}

The interphase microtubular arrays of onion (Allium cepa L.) root meristem cells were visualized with indirect immunofluorecsence. Two kinds of cytoplasmic microtubules were distinguished in each interpahse cell: cortical and endoplasmic. The cortical microtubules are arranged in an irregular network in isodiametric cells, ribbons running round the long cell axis in some slightly elongated cells and ribbons or rings perpendicular to the long cell axis in 
elongated cells. The endoplasmic microtubules form a tridimensional network in the endoplasm. Both populations of microtubules behave as two distinct units during preprophase and they exhibit different sensitivity to the action of colchicine.

\section{Acknowledgement}

The authors thank L. Leyssen for preparation of the micrographs and the group of the Division of Cellular Biology and Chemotherapy, Janssen Pharmaceutica Res. Lab. (Beerse, Belgium) for their help in carrying out experiments. Special thanks are expressed to Drs Marc De Brabander, Jan De Mey and Prof. Andrew Bajer for valuable discussions and critical reading of the manuscript.

\section{References}

Brinkley, B. R., Fuller, G. M. and Highfield, D. P. 1975. Studies of microtubules in dividing and non-dividing mammalian cells using antibody to 6-S bovine brain tubulin. In: Microtubules and Microtubule Inhibitors, 1975, Borgers, M., De Brabander, M. ed. Elsevier, North Holland Biomedical Press, Amsterdam.

Clayton, L. and Lloyd, C. W. 1984. The ralationships between the division plane and spindle geometry in Allium cells treated with CIPC and griseofulvin: an antitubulin study. Europ. J. Cell Biol. 34: 248-253.

De Mey, J., Lambert, A. M., Bajer, A. S., Moeremans, M. and De Brabander, M. 1982. Visualization of microtubules in interphase and mitotic plant cells of Haemanthus endosperm with the immuno-gold staining method. Proc. Nat. Acad. Sci. USA 79: 1898-1902.

Dickinson, H. G. and Sheldon, J. M. 1984. A radial system of microtubules extending between the nuclear envelope and the plasma membrane during early male hyplophase in flowering plants. Planta 161: 86-90.

Dustin, P. 1978. Microtubules. Springer, Berlin, Heidelberg, New York.

Gunning, B. E. S. and Hardham, A. R. 1979. Microtubules and morphogenesis in plants. Endeavour 3: 112-117.

Hardham, A. R. and Gunning, B. E. S. 1977. The length and disposition of cortical microtubules in plant cells fixed in glutaraldehyde-osmium tetroxide. Planta 134: 201-203.

- and - 1978. Structure of cortical microtubules arrays in plant cells. J. Cell Biol. 77: 14-34.

Heath, J. B. 1974. A unified hypothesis for the role of membrane bound enzyme complexes and microtubules in plant cell wall synthesis. J. Theor. Biol, 48: 445-449.

Kubiak, J., De Brabander, M., De Mey, J. and Tarkowska, J. A. 1985. Origin of the mitotic spindle in onion root cells. Protoplasma 30: 51-56.

Ledbetter, M. C. and Porter, K. R. 1970. Introduction to the Fine Structure of Plant Cells. Springer-Verlag, Berlin, Heidelberg, New York.

Lloyd, C. W., Slabas, A. R., Powell, A. J., Mac Donald, G. and Badley, A. R. 1979. Cytoplasmic microtubules of higher plant cells visualized with antitubulin antibodies. Nature (London) 279: 239-241.

-, - - - and Lowe, S. B. 1980. Microtubules, protoplasts and plant cell shape. An immunofluorescent study. Planta 147: 500-506.

Mita, T. and Shibaoka, H. 1983. Changes in microtubules in onion leaf sheath cells during bulb development. Plant and Cell Physiol. 24: 109-117.

Molè-Bajer, J. and Bajer, A. S. 1983. Action of taxol on mitosis: Microtubule arrangements and function of the mitotic spindle in Haemanthus endosperm. J. Cell Biol. 96: 527-540.

Schmit, A. C., Vantard, M., De Mey, J., Lambert, A. M. 1983. Aster-like microtubule centers establish spindle polarity during interphase-mitosis transition in higher plant cells. Plant Cell Rep. 2: 285-288.

Simmonds, D., Setterfield, G., Tanchak, M., Brown, D. L. and Rogers, K. A. 1982. Microtubule organization in culture plant cells. In: Plant Tissue Culture 1982, Proc. 5th Int. Cong. Plant Tissue and Cell Culture.

- - and Brown, D. L. 1983a. Organization of microtubules in dividing and elongating cells of Vicia hajastana Grossh. in suspension culture. Europ. J. Cell Biol. 32: 59-66.

-, - and - 1983b. Reorganization of microtubules in protoplasts of Vicia hajastana Grossh. during the first 48 hours of culturing. 6th Int. Protoplast Symp. 
Weber, K., Pollack, R. and Bibring, T. 1975. Antibody against tubulin: The specific visualization of cytoplasmic microtubules in tissue culture cells. Proc. Nat. Acad. Sci. USA. 72: 459-463.

Wick, S. M. and Duniec, J. 1983. Immunofluorescence microscopy of tubulin and microtubule arrays in plant cells I. Preprophase band development and concomitant appearance of nuclear envelope-associated tubulin. J. Cell Biol. 97 : 235-243.

-, Seagull, R. W., Weber, K. and Gunning, B. E. S. 1981. Immunoflorescence microscopy of organized microtubule arrays in structurally stabilized meristematic plant cells. J. Cell Biol. 89: 685-690. 